\title{
Investigation of Learner Recognition to Introduction of Mobile Learning: A Study Targeting Officers at the Ministry of Health and Welfare in Korea
}

\author{
Sunmi Jin \\ Korea Human Resource Development \\ Institute for Health \&Welfare, South, Korea \\ Seunghye Hyun \\ The Department of Educational technology \\ Hanyang University, South, Korea
}

\begin{abstract}
Mobile learning is a practical learning method for busy adult learners because the mobility of digital devices can overcome the drawbacks of e-learning. However, research is strongly lacking in the theoretical exploration of mobile learning effects and functions and its empirical research. Moreover, the research of learning characteristics and learners' requirements must be considered before applying and disseminating mobile learning into the educational field. To address this shortcoming, this study conducted an online survey with 1,542 officers of the Ministry of Health and Welfare Affairs (MHWA) regarding learner recognition to mobile learning. The analysis of learners' attitudes toward mobile learning, based on age and position, indicated that subordinate workers appeared to place more value on mobile learning. Many participants preferred mobile learning because of its mobility and the effectiveness of anywhere and anytime. However, some participants continue to misunderstand mobile learning and its necessity. Therefore, consideration of learning effectiveness, the form of the content, and learner-centered learning must be reviewed in advance. This study could lead to practical implications of mobile learning.
\end{abstract}

Key words: Mobile Learning, Recognition of Learner, Case Study.

\section{INTRODUCTION}

The mobile learning has been significantly important in higher education with cutting-edge information communication technology available throughout the world. Especially the mobile devices and the web have changed the world in a very short period of time [1]. With the development of wireless internet and various mobile communication devices, one can have access to the internet in order to search and acquire the information one needs [2]. Thus, e-learning based on cable internet is currently transforming into the mobile learning environment [3] - [5].

Recently, the spread of the smart phone and the development of its application have led to increasing attention toward mobile learning services. Smart phone users increased from 80 million in late 2009 to 1000 million by March 2011 . Smart phone users are expected to increase to 2,000 million (Korea Communication Commission), which occupies $40 \%$ of mobile phone users [6]. As it can incorporate the busy life style

* Corresponding author,Email: micojin@kohi.or.kr Manuscript received May. 02, 2014; revised Aug. 25, 2014; accepted Sep. 01, 2014 of users into the era of 'one-man-one-mobile device', mobile learning is likely to receive more attention in the near future. Mobile technology allows one to access the internet without time and space limits, and this leads to a new technological paradigm. Mobility, accessibility, individual recognition, interaction, and synchronous interaction can maximize effective learning in the teaching-learning process. Mobile learning incorporates the merits of e-learning. At the same time, mobile learning overcomes the drawbacks of e-learning, thus, opening the possibility of a new educational paradigm. However, this is still a new development, and therefore a thorough investigation is needed.

Even though a newly introduced learning method is innovative, a careful investigation and a gradual introduction should be required into the educational field. Researchers also should consider learner characteristics and needs. Especially, within the changed paradigm of movement from a supplierbased environment into a consumer-based environment, a broad understanding about various learners and their needs is needed. This means a thorough understanding about learners' thoughts, attitudes, and pre-required needs is required. Consequently, these principles can be applied into new and innovative educational trends [7]. To do this, a broad analysis of learners' mobile learning and pre-required needs is required 
in order to develop this educational system. To conduct this, a specific learner group should be chosen. In a specialized officer education training institute such as the Human Resources Department at the Ministry of Health and Welfare, learner characteristics and needs vary; thus, it would be possible to conduct a cross-tabulation regarding learner recognitions according to learner characteristics [8]. Therefore, the current study aims to analyze learners' awareness of mobile learning and explores the concept of mobile learning. In so doing, it elicits the practical implications of introducing mobile learning.

\section{LITERATURE REVIEW}

\subsection{Mobile learning}

Mobile is defined as 'portable', 'active', and 'easy to move' and it is currently receiving much attention as an ideal learning device. Cell phones, smart phones, personal computer handheld devices, Tablet PCs, lap tops, and personal media players are commonly used devices. Through mobile devices and wireless networks, mobile technology has the characteristics of mobility. This is one of the biggest strengths and features of mobile learning. Through the mobility of the smart phone, one can have access to information he or she needs and communicate it to colleagues without time and space restraints [9].

By applying the mobility of mobile technology into education, learning can be possible without time and space restraints. This is defined as mobile learning (mobile learning: m-learning) [10], [11]. Mobile learning is one of the alternatives to e-learning. Mobile learning can be considered as a type of distance learning and it can overcome the limits of computer learning based on a wire based network [12] - [14]. Moreover, this can be categorized as a Computer Assisted Instruction (CAI). However, in both studies, through the mobility of the mobile device, learning space is extended and learners can participate in situated learning using location based information. Also, through Social Network Services(SNS) of cell phones, interactive learner based learning is integrated [15], [16]. Recently, an understanding of transforming learning progress through mobility and interaction with various and different people is another characteristic and merit of mobile learning [17]. To sum up, the present study defined mobile learning as a learning portal that links learners' formal learning and informal learning and allows learners to form their own knowledge through interactions with various learners including peers and professionals. Thus, mobile learning can have various forms, including being an alternative to e-learning as well as face-to-face learning. However, mobile learning methods should be designed and managed based on the features of learning fields [18].

\subsection{Survey of learner awareness toward acceptance of mobile learning}

In the initial stage of the introduction of mobile learning, several trials and errors can occur if it does not have a systematic plan [12]. Such trials and errors already took place with the introduction of e-learning and it can be blamed on political, social, and economical features. Also, structure and organization of education and training institutes, attitudes, compensation systems, officers' values, individual political power, and standards based on the end-product can be other reasons that cause such trials and errors [19]. These features can be viewed according to several aspects including organizational, social, personal, and political. Considering such aspects, at the stage when a new technology is introduced, one of the most common features that receive attention is how well it is accepted and spread based on the user's decision making process [20].

The importance of the individual can be viewed from several angles. In the field of educational technology, factors that interrupt the spread of innovation are learners' recognition and application rather than lack of hardware and software [21]. Moreover, the selection of new educational methods should be based on individual choice rather than enforcement because it is more effective for individuals to make their own decision regarding the utility of a new educational method. Recognition toward acceptance of a new learning method can vary from strongly positive attitudes toward strongly negative attitudes. Such variations of recognition can be obvious when one can accept and spread new learning methods based on one's decision making process. Therefore, in order to use and spread new innovative mobile learning, investigation of learners' recognition based on individual decision making factors is needed. Therefore, the analysis of learners' recognition and attitude toward the introduction of mobile learning would be necessary.

In terms of learner aspects, learner background, motivation, and usability should be analyzed. Regarding the spread of learning methods based on new tools, learners' skills to use software, preparation of hardware, and familiarity toward this learning method should be reviewed. Types of mobiles, one's proficiency of using the mobile, and the familiarity of learning method influence the effects of learning because one's initial experience of a new learning method can play an influential role on one's recognition toward mobile learning [22]. Therefore, before introducing a mobile learning method, an investigation into learner recognition of the above categories is needed.

\section{RESEARCH METHOD}

\subsection{Participants}

In this study, 1,543 participants who were interested in mobile learning voluntarily completed a cyber-learning project. We chose 1,543 participants because they have experienced of e-learning and have basic knowledge of the cyber-learning so they can compare e-learning with mobile learning' advantages.

980 of participants are female $(65.5 \%)$ and $563(36.5 \%)$ were male. The dominant age group was 40 years $(685$ participants, $44.4 \%)$, followed by $50 \mathrm{~s}(454,29.4 \%), 30 \mathrm{~s}(329$, $21.3 \%$ ) and $20 \mathrm{~s}(75,4.9)$. The dominant job position was 968 action officers( $62.7 \%)$, followed by 255 others(16.5\%), 249 degree8-degrees(16.1\%) and 10 deputy directors(4.6\%). Basic information of the participants can be seen from the following Table 1 . The survey was completed and conducted by online email from June 16th to July 15th in 2011. 
Table 1. Description of sample

\begin{tabular}{|c|c|c|c|}
\hline \multicolumn{2}{|c|}{ Variables } & Frequency(N) & Percent (\%) \\
\hline \multirow{2}{*}{ Gender } & Male & 563 & 36.5 \\
\hline & Female & 980 & 63.5 \\
\hline \multirow{4}{*}{ Age } & $20 \mathrm{~s}$ & 75 & 4.9 \\
\hline & $30 \mathrm{~s}$ & 329 & 21.3 \\
\hline & $40 \mathrm{~s}$ & 685 & 44.4 \\
\hline & over $50 \mathrm{~s}$ & 454 & 29.4 \\
\hline \multirow{4}{*}{ Position } & Deputy director & 71 & 4.6 \\
\hline & Action officer & 968 & 62.7 \\
\hline & Degree8-degree10 & 249 & 16.1 \\
\hline & Others & 255 & 16.5 \\
\hline \multicolumn{2}{|r|}{ Total } & 1,543 & 100.0 \\
\hline
\end{tabular}

\subsection{Instruments}

This study covered the following areas: understanding of the mobile learning, usability of mobile devices, experience of mobile learning, factors affecting the use of mobile learning methods and learning contents, the availability of mobile learning, and a plan for mobile learning distribution to the participants.

The survey questionnaire consisted of 29 items was including closed questions and open-ended questions on a fivepoint Likert rating scale to collect and analyze quantitative and qualitative information at the same time. The initial questionnaire was developed by two educational technologists and then reviewed and refined for validity of the items by two doctoral researchers for reliability of measurement. The collected data was analyzed by descriptives, frequencies, t-test, and one-way ANOVA.

\subsection{Procedure}

First, the investigation of the learner recognitions toward the introduction of mobile learning was conducted based on the literature review and preceding research.

Second, based on previous research, the survey of questionnaire was developed and refined by two educational specialists and two doctoral researchers regarding a mobile learning service, previous experience of mobile learning, factors affecting the use of mobile learning, the availability of mobile learning, and a plan for mobile learning distribution to the participants.

Third, 1,543 subjects who were completed the cyber learning of MHWA answered e-mail version of the survey.

The form of the survey was based on five-point LikertScale. The Cronbach's $\propto$ of the instrument in the present study is .933. Results of reliabilities coefficients for satisfaction scale are presented in Table 2.

Table 2. Reliabilities Coefficients of Satisfaction Scale

\begin{tabular}{|c|c|}
\hline Cronbach's Alpha & N of items \\
\hline .933 & 54 \\
\hline
\end{tabular}

Finally, SPSS 18 for the collected data was used to perform all statistical analysis, Mean, SD, t-test, one-way
ANOVA, and Scheffe for post-hoc analysis to identify significant differences between gender, age and positions.

\section{RESULTS}

In responding to the question whether learners have experience of using mobile learning, 1,479 (95.9\%) participants responded that they had not experienced it and only 64 (4.1\%) replied that they had experienced mobile learning. Targeting those who had not experienced mobile learning, the researchers asked the question whether those learners had plans to use mobile learning in the future. Among 1,479 (95.9\%), 984 $(66.5 \%)$ answered they do not plan to use mobile learning whereas $495(33.5 \%)$ showed their willingness to use mobile learning in the future.

\subsection{Mobile learning service and learning method}

As mentioned earlier, in responding to the question whether learners have experience of mobile learning, 1,479 (95.9\%) responded that they had not experienced mobile learning. According to those participants, 497 (33.6\%) did not use mobile learning because they did not see the necessity of it. Also, 334 (22.6\%) did not use mobile learning because of the small and uncomfortable devices. $262(17.7 \%)$ responded that they did not even know about the concept of mobile learning and $250(16.9 \%)$ did not use mobile learning because of the expensive price. Considering these responses from the participants, in order to introduce mobile learning effectively, explanation about the utility of mobile learning and an operation manual using flash animation is needed.

Table 3. Reasons for not using mobile learning

\begin{tabular}{|l|c|}
\hline \multicolumn{1}{|c|}{ Category } & Percent (\%) \\
\hline expensive price & $250(16.9 \%)$ \\
\hline unsatisfied contents & $8(0.5 \%)$ \\
\hline $\begin{array}{l}\text { do not see the necessity of mobile } \\
\text { learning }\end{array}$ & $497(33.6 \%)$ \\
\hline slow speed of wireless internet & $55(3.7 \%)$ \\
\hline $\begin{array}{l}\text { do not know the concept of mobile } \\
\text { learning }\end{array}$ & $262(17.7 \%)$ \\
\hline small and uncomfortable device & $334(22.6 \%)$ \\
\hline others & $73(4.9 \%)$ \\
\hline
\end{tabular}

Table 4. Mobile learning service and learning method

\begin{tabular}{|c|l|c|}
\hline \multicolumn{2}{|c|}{ Category } & Percent (\%) \\
\hline \multirow{2}{*}{} & $\begin{array}{l}\text { view new learning contents } \\
\text { review previous learning } \\
\text { contents }\end{array}$ & $802(52.0 \%)$ \\
\cline { 2 - 3 } $\begin{array}{c}\text { wanted } \\
\text { mobile } \\
\text { learning } \\
\text { service }\end{array}$ & $\begin{array}{l}\text { test learned contents } \\
\text { through game }\end{array}$ & $434(24.9 \%)$ \\
\cline { 2 - 3 } & \begin{tabular}{l} 
problem solving with peers \\
\cline { 2 - 3 }
\end{tabular} & $\begin{array}{l}\text { question about the learned } \\
\text { contents }\end{array}$ \\
\cline { 2 - 3 } & $24(1.6 \%)$ \\
\hline
\end{tabular}




\begin{tabular}{|c|c|c|}
\hline & others & $22(1.4 \%)$ \\
\hline \multirow{6}{*}{$\begin{array}{l}\text { wanted } \\
\text { mobile } \\
\text { learning } \\
\text { method }\end{array}$} & game & $109(7.1 \%)$ \\
\hline & cartoon & $203(13.2 \%)$ \\
\hline & text message & $228(14.8 \%)$ \\
\hline & quiz & $158(10.2 \%)$ \\
\hline & animation & 824 (53.4\%) \\
\hline & other uses & $21(1.4 \%)$ \\
\hline
\end{tabular}

\subsection{Experience about mobile learning}

\subsubsection{Commonly used mobile learning contents}

Targeting the participants who had experienced mobile learning, the researchers asked the questions about their commonly used mobile learning contents, learning method, place of conducting mobile learning, reasons for using mobile learning, and factors that interrupt mobile learning. In responding to the question about the commonly used mobile learning contents, $21(32.8 \%)$ participants responded that they use mobile learning when they study language; while 17 (26.6\%) replied that they use it for duty-related education, 11 $(17.2 \%)$ responded for hobbies, nine $(14.1 \%)$ use mobile learning for cyber and degree-related learning, four $(6.3 \%)$ take advantage of mobile learning for certification-related education, and only two (3.1\%) replied for other uses.

\subsubsection{The most commonly used mobile learning method}

In responding to the question regarding the most commonly used mobile learning method, 21 (32.8\%) responded that they used mobile learning through the form of synchronous video lecture, internet lecture, and web-based searching; while $16(25.0 \%)$ downloaded files (video/audio). Such responses imply that learners use the mobility of mobile learning as a form of e-learning. Moreover, 13 (20.3\%) answered that they downloaded educational applications, ten (15.6\%) replied they accessed wireless internet, and only three (4.7\%) replied they used the internal learning contents of the mobile devices, and one $(1.6 \%)$ responded to other uses.

\subsubsection{Place to use mobile learning}

In responding to the question regarding the place to use mobile learning, $24(37.5 \%)$ responded at home whereas 20 $(31.3 \%)$ answered on transportation (subway, bus, and car). Moreover, $16(25.0 \%)$ replied they would use mobile learning while they are at their work. Also, three (4.7\%) use it outdoors such as in the mountain, parks, and resort areas, and only one $(1.6 \%)$ replied for other places.

Table 5. Performance of mobile learning

\begin{tabular}{|c|c|c|}
\hline \multicolumn{2}{|r|}{ Category } & Percent (\%) \\
\hline \multirow{3}{*}{$\begin{array}{l}\text { mobile } \\
\text { learning } \\
\text { contents }\end{array}$} & language & $21(32.8 \%)$ \\
\hline & $\begin{array}{l}\text { certification-related } \\
\text { education }\end{array}$ & $4(6.3 \%)$ \\
\hline & $\begin{array}{l}\text { cyber/degree-related } \\
\text { education }\end{array}$ & $9(14.1 \%)$ \\
\hline
\end{tabular}

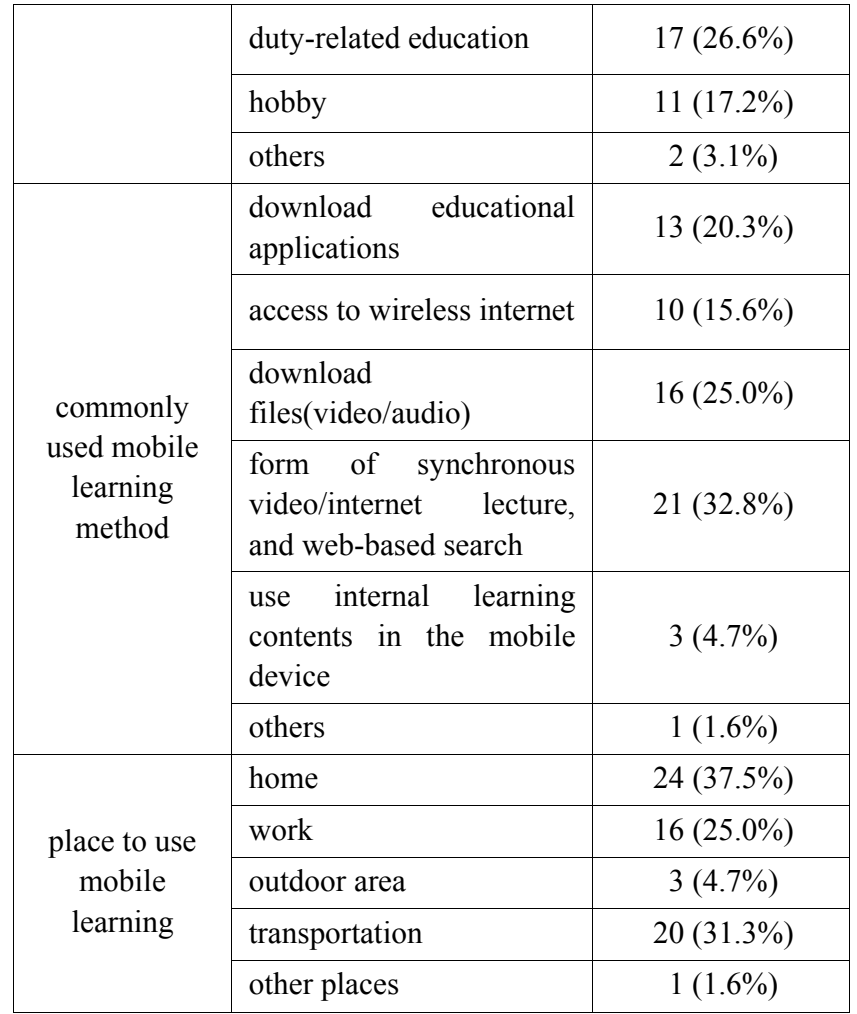

\subsection{Factors affecting mobile learning}

\subsubsection{Reasons for mobile learning}

In responding to the question of underlying reasons for using mobile learning, $34(53.1 \%)$ responded that they use mobile learning because of the good accessibility. This response implies that the participants placed value on the mobility of mobile learning. Furthermore, 13 (20.3\%) answered that they used it because they can enjoy their leisure time through mobile learning. Six (9.4\%) showed they used mobile learning because it can maximize learning effect. Moreover, four $(6.3 \%)$ answered they used mobile learning because it is interesting. Those four participants also placed values on mobile learning due to its updated learning contents.

\subsubsection{Factors that interrupt mobile learning}

In responding to the question regarding the factors that interrupt mobile learning, 17 (26.6\%) responded that the small screen of the device and difficult operation of the device are the main interrupting factors. $16(25.0 \%)$ answered for slow speed and unstable status of the internet. Ten (15.6\%) responded for expensive internet fees and nine (14.1\%) replied for limited learning contents. five $(7.8 \%)$ answered that complicated usage of the mobile device is the main factor that interrupts mobile learning, and seven (10.9\%) responded for other reasons.

Table 6. Factors of using mobile learning

\begin{tabular}{|c|l|c|}
\hline \multicolumn{2}{|c|}{ Category } & Percent (\%) \\
\hline \multirow{2}{*}{$\begin{array}{c}\text { reasons of } \\
\text { using mobile } \\
\text { learning }\end{array}$} & maximize the effects of learning & $6(9.4 \%)$ \\
\cline { 2 - 3 } & accessibility (time and place) & $34(53.1 \%)$ \\
\cline { 2 - 3 } & easy to operate & $4(6.3 \%)$ \\
\hline
\end{tabular}




\begin{tabular}{|c|l|c|}
\hline \multirow{4}{*}{} & use one's leisure time & $13(20.3 \%)$ \\
\cline { 2 - 3 } & select one's learning progress & $3(4.7 \%)$ \\
\cline { 2 - 3 } & view updated learning contents & $4(6.3 \%)$ \\
\hline \multirow{4}{*}{$\begin{array}{c}\text { interrupting } \\
\text { factors of } \\
\text { mobile } \\
\text { learning }\end{array}$} & expensive mobile internet fee & $10(15.6 \%)$ \\
\cline { 2 - 3 } & $\begin{array}{l}\text { small screen of the device } \\
\text { difficult usage of the device }\end{array}$ & $17(26.6 \%)$ \\
\cline { 2 - 3 } & complicate to operate & $5(7.8 \%)$ \\
\cline { 2 - 3 } & $\begin{array}{l}\text { limited learning contents } \\
\text { llow speed and unstable status of }\end{array}$ & $9(14.1 \%)$ \\
\cline { 2 - 3 } & other reasons & $7(10.9 \%)$ \\
\hline
\end{tabular}

4.4 Availability to use mobile learning device and plans to use

\subsubsection{Availability to use mobile learning device}

Regarding the availability to use mobile learning device, the participants showed 3.03-3.13 in responding to the question of one's ability to use mobile learning device. This implies that mobile learning ability is not an interrupting factor in mobile learning.

Table 7. Availability of mobile learning device

\begin{tabular}{|c|c|}
\hline \multicolumn{1}{|c|}{ Category } & Mean \pm SD \\
\hline $\begin{array}{l}\text { I believe using mobile device in learning } \\
\text { is easy. }\end{array}$ & $3.13 \pm 0.943$ \\
\hline $\begin{array}{l}\text { I believe ability to use mobile device in } \\
\text { mobile learning is sufficient. }\end{array}$ & $3.03 \pm 0.962$ \\
\hline $\begin{array}{l}\text { I believe operation to use mobile learning } \\
\text { device and related software is easy. }\end{array}$ & $3.03 \pm 0.902$ \\
\hline $\begin{array}{c}\text { I can easily download and save the } \\
\text { learning contents I need. }\end{array}$ & $3.08 \pm 0.933$ \\
\hline
\end{tabular}

The following is the difference in the respondents' availability to use mobile learning according to gender. In all the categories, a significant difference is shown according to gender. More specifically, males showed higher means than females.

Table 8. Availability of mobile learning use according to gender

\begin{tabular}{|l|c|c|c|c|c|c|}
\hline \multirow{2}{*}{ Items } & \multicolumn{2}{|c|}{ Male } & \multicolumn{2}{|c|}{ Female } & \multirow{2}{*}{$\mathrm{t}$} & $\mathrm{p}$ \\
\cline { 2 - 6 } & $\mathrm{M}$ & $\mathrm{SD}$ & $\mathrm{M}$ & $\mathrm{SD}$ & & \\
\hline $\begin{array}{l}\text { I believe the } \\
\text { operation to } \\
\text { use mobile } \\
\text { learning is } \\
\text { easy. }\end{array}$ & 3.21 & 0.963 & 3.09 & 0.930 & 2.38 & $0.017^{*}$ \\
\hline $\begin{array}{l}\text { I believe my } \\
\text { ability to use } \\
\text { mobile learning } \\
\text { device in } \\
\text { mobile learning } \\
\text { is sufficient. }\end{array}$ & 3.12 & 0.972 & 2.98 & 0.952 & 2.75 & $0.006^{* *}$ \\
\hline
\end{tabular}

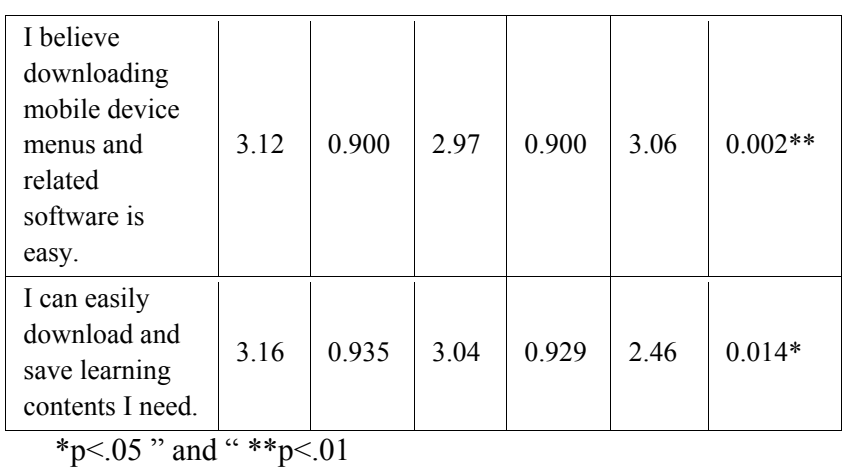

The following is the analyzed result of the availability of mobile learning according to age. In all the categories, a significant difference is shown. More specifically, those in their 20 s showed higher means compared to other age groups.

Table 9. Availability of mobile learning according to age

\begin{tabular}{|c|c|c|c|c|c|}
\hline $\begin{array}{c}\text { Dependent } \\
\text { variable }\end{array}$ & Age & $\mathrm{M}$ & $\mathrm{SD}$ & $\begin{array}{l}\mathrm{F} / \mathrm{p}- \\
\text { value }\end{array}$ & Scheffe \\
\hline \multirow{4}{*}{$\begin{array}{l}\text { I believe the } \\
\text { operation to } \\
\text { use mobile } \\
\text { learning is } \\
\text { easy. }\end{array}$} & $20 \mathrm{~s}(\mathrm{a})$ & 3.48 & 0.794 & \multirow{4}{*}{$\begin{array}{l}13.151 \\
/ 0.000\end{array}$} & \multirow{4}{*}{$\begin{array}{c}\mathrm{d}<\mathrm{c}<\mathrm{a} \\
\mathrm{d}<\mathrm{b}\end{array}$} \\
\hline & $30 \mathrm{~s}(\mathrm{~b})$ & 3.31 & 0.903 & & \\
\hline & $40 \mathrm{~s}(\mathrm{c})$ & 3.13 & 0.917 & & \\
\hline & $\begin{array}{l}\text { above } \\
50 \mathrm{~s}(\mathrm{~d})\end{array}$ & 2.95 & 0.994 & & \\
\hline \multirow{3}{*}{$\begin{array}{l}\text { I believe my } \\
\text { ability to use } \\
\text { mobile } \\
\text { learning } \\
\text { device in } \\
\text { mobile } \\
\text { learning is } \\
\text { sufficient. }\end{array}$} & $20 \mathrm{~s}$ & 3.51 & 0.860 & \multirow[b]{3}{*}{$\begin{array}{l}19.632 \\
/ 0.000\end{array}$} & \multirow[b]{3}{*}{$\begin{array}{l}\mathrm{d}<\mathrm{c}<\mathrm{a} \\
\mathrm{d}<\mathrm{c}<\mathrm{b}\end{array}$} \\
\hline & $30 \mathrm{~s}$ & 3.25 & 0.927 & & \\
\hline & $\begin{array}{l}40 \mathrm{~s} \\
\text { above } \\
50 \mathrm{~s}\end{array}$ & 3.01 & 0.948 & & \\
\hline \multirow[b]{2}{*}{$\begin{array}{l}\text { I believe } \\
\text { downloading } \\
\text { mobile device } \\
\text { menus and } \\
\text { related } \\
\text { software is } \\
\text { easy. }\end{array}$} & $20 \mathrm{~s}$ & 3.45 & 0.843 & \multirow[b]{2}{*}{$\begin{array}{l}17.381 \\
/ 0.000\end{array}$} & \multirow[b]{2}{*}{$\begin{array}{l}\mathrm{d}<\mathrm{c}<\mathrm{a} \\
\mathrm{d}<\mathrm{c}<\mathrm{b}\end{array}$} \\
\hline & $\begin{array}{l}30 \mathrm{~s} \\
40 \mathrm{~s} \\
\text { above } \\
50 \mathrm{~s}\end{array}$ & $\begin{array}{l}3.22 \\
3.01\end{array}$ & $\begin{array}{l}0.865 \\
0.888 \\
0.912\end{array}$ & & \\
\hline \multirow{4}{*}{$\begin{array}{l}\text { I can easily } \\
\text { download and } \\
\text { save learning } \\
\text { contents I } \\
\text { need. }\end{array}$} & $20 \mathrm{~s}$ & 3.48 & 0.875 & \multirow{4}{*}{$\begin{array}{l}18.444 \\
/ 0.000\end{array}$} & \multirow{4}{*}{$\begin{array}{l}\mathrm{d}<\mathrm{c}<\mathrm{a} \\
\mathrm{d}<\mathrm{c}<\mathrm{b}\end{array}$} \\
\hline & $30 \mathrm{~s}$ & 3.28 & 0.883 & & \\
\hline & $40 \mathrm{~s}$ & 3.09 & 0.909 & & \\
\hline & $\begin{array}{l}\text { above } \\
50 \mathrm{~s}\end{array}$ & 2.86 & 0.959 & & \\
\hline \multirow{3}{*}{$\begin{array}{l}\text { I believe } \\
\text { using the } \\
\text { contents of } \\
\text { mobile } \\
\text { learning is } \\
\text { easy. }\end{array}$} & $20 \mathrm{~s}$ & 3.56 & 0.740 & \multirow{3}{*}{$\begin{array}{l}22.261 \\
/ 0.000\end{array}$} & \multirow{3}{*}{$\mathrm{d}<\mathrm{c}<\mathrm{b}<\mathrm{a}$} \\
\hline & $\begin{array}{l}30 \mathrm{~s} \\
40 \mathrm{~s}\end{array}$ & $\begin{array}{l}3.23 \\
3.06\end{array}$ & $\begin{array}{l}0.887 \\
0.903\end{array}$ & & \\
\hline & $\begin{array}{l}\text { above } \\
50 \mathrm{~s}\end{array}$ & 2.82 & 0.917 & & \\
\hline
\end{tabular}

The following is the analyzed result of the availability of mobile learning according to position. In all the categories, a significant difference is shown. More specifically, in the categories including 'I believe the operation to use mobile 
learning is easy', 'I believe downloading mobile device menus and related software is easy', and 'I believe downloading mobile device menus and related software is easy', subordinates show higher means than middle-position managers. In the category of 'I believe my ability to use mobile learning device in mobile learning is sufficient', subordinates showed higher availability compared to managers and middle-position managers. Regarding others, middle-position managers showed higher means than subordinates.

Table 10. Availability of mobile learning according to position

\begin{tabular}{|c|c|c|c|c|c|}
\hline $\begin{array}{l}\text { Dependent } \\
\text { variable }\end{array}$ & Position & M & $\mathrm{SD}$ & $\begin{array}{l}\text { F/p- } \\
\text { value }\end{array}$ & Scheffe \\
\hline \multirow{4}{*}{$\begin{array}{l}\text { I believe } \\
\text { operation to } \\
\text { use mobile } \\
\text { learning is } \\
\text { easy. }\end{array}$} & manager(a) & 2.99 & 0.978 & \multirow{4}{*}{$\begin{array}{r}4.460 \\
/ 0.004\end{array}$} & \multirow{4}{*}{$\mathrm{b}<\mathrm{c}$} \\
\hline & $\begin{array}{l}\text { middle } \\
\text { manager(b) }\end{array}$ & 3.08 & 0.943 & & \\
\hline & $\begin{array}{l}\text { subordinate } \\
\text { workers(c) }\end{array}$ & 3.28 & 0.912 & & \\
\hline & other (d) & 3.23 & 0.943 & & \\
\hline \multirow{4}{*}{$\begin{array}{l}\text { I believe my } \\
\text { ability to use } \\
\text { mobile learning } \\
\text { device in } \\
\text { mobile learning } \\
\text { is sufficient. }\end{array}$} & managers & 2.86 & 0.960 & \multirow{4}{*}{$\begin{array}{l}9.679 \\
/ 0.000\end{array}$} & \multirow{4}{*}{$\begin{array}{l}\mathrm{a}<\mathrm{c} \\
\mathrm{b}<\mathrm{c} \\
\mathrm{b}<\mathrm{d}\end{array}$} \\
\hline & $\begin{array}{l}\text { middle } \\
\text { managers }\end{array}$ & 2.95 & 0.962 & & \\
\hline & $\begin{array}{l}\text { subordinate } \\
\text { workers }\end{array}$ & 3.25 & 0.943 & & \\
\hline & other & 3.18 & 0.930 & & \\
\hline \multirow{4}{*}{$\begin{array}{l}\text { I believe } \\
\text { downloading } \\
\text { mobile device } \\
\text { menus and } \\
\text { related } \\
\text { software is } \\
\text { easy. }\end{array}$} & managers & 2.86 & 0.915 & \multirow{4}{*}{$\begin{array}{l}6.056 \\
/ 0.000\end{array}$} & \multirow{4}{*}{$b<c$} \\
\hline & $\begin{array}{l}\text { middle } \\
\text { managers }\end{array}$ & 2.97 & 0.902 & & \\
\hline & $\begin{array}{l}\text { subordinate } \\
\text { workers }\end{array}$ & 3.19 & 0.889 & & \\
\hline & others & 3.13 & 0.886 & & \\
\hline \multirow{4}{*}{$\begin{array}{l}\text { I can easily } \\
\text { download and } \\
\text { save learning } \\
\text { contents I need. }\end{array}$} & managers & 2.94 & 0.969 & \multirow{4}{*}{$\begin{array}{l}4.718 \\
/ 0.003\end{array}$} & \multirow{4}{*}{$\mathrm{b}<\mathrm{c}$} \\
\hline & $\begin{array}{l}\text { middle } \\
\text { managers }\end{array}$ & 3.03 & 0.925 & & \\
\hline & $\begin{array}{l}\text { subordinate } \\
\text { workers }\end{array}$ & 3.23 & 0.908 & & \\
\hline & others & 3.18 & 0.955 & & \\
\hline \multirow{4}{*}{$\begin{array}{l}\text { I believe using } \\
\text { the contents } \\
\text { of mobile } \\
\text { learning is } \\
\text { easy. }\end{array}$} & managers & 2.93 & 0.915 & \multirow{4}{*}{$\begin{array}{l}7.327 \\
/ 0.000\end{array}$} & \multirow{4}{*}{$\begin{array}{l}\mathrm{b}<\mathrm{c} \\
\mathrm{b}<\mathrm{d}\end{array}$} \\
\hline & $\begin{array}{l}\text { middle } \\
\text { managers }\end{array}$ & 2.98 & 0.907 & & \\
\hline & $\begin{array}{l}\text { subordinate } \\
\text { workers }\end{array}$ & 3.21 & 0.909 & & \\
\hline & others & 3.20 & 0.915 & & \\
\hline
\end{tabular}

\subsubsection{Attitudes toward mobile learning}

Regarding attitudes toward mobile learning, all the categories showed scores range from 3.27 to 3. 55. This implies that the mainly have positive attitudes toward mobile learning. More specifically, within the environment of qualified contents and mobile-friendly environment, the participants showed the strongest willingness to use mobile learning (score 3.55).
Table 11. Attitudes toward mobile learning

\begin{tabular}{|l|l|}
\hline \multicolumn{1}{|c|}{ Category } & Mean \pm SD \\
\hline $\begin{array}{l}\text { Using mobile learning, I believe I can } \\
\text { maximize learning effects compared to } \\
\text { previous learning method (offline, cyber). }\end{array}$ & $3.27 \pm .877$ \\
\hline $\begin{array}{l}\text { I believe I can easily learn the functions of } \\
\text { mobile-learning device. }\end{array}$ & $3.35 \pm .850$ \\
\hline $\begin{array}{l}\text { I believe application of mobile learning } \\
\text { would be easy because it is similar to web- } \\
\text { based learning. }\end{array}$ & $3.31 \pm .85$ \\
\hline $\begin{array}{l}\text { Within the environment of qualified } \\
\text { contents and mobile-friendly environment, I } \\
\text { would actively use it. }\end{array}$ & $3.55 \pm .909$ \\
\hline $\begin{array}{l}\text { I have positive attitudes toward mobile } \\
\text { learning. }\end{array}$ & $3.54 \pm .893$ \\
\hline $\begin{array}{l}\text { I would like to actively use mobile learning } \\
\text { in the future. }\end{array}$ & $3.41 \pm .947$ \\
\hline
\end{tabular}

The following is the analyzed result of attitudes toward mobile learning according to gender. In responding to the categories of 'Using mobile learning, I believe I can maximize learning effects compared to previous learning method (offline, cyber)' and 'Within the environment of qualified contents and mobile-friendly environment, I would actively use it', the result showed significant difference. More specifically, males showed higher average points than females.

Table 12. Attitudes toward mobile learning according to gender

\begin{tabular}{|l|c|c|c|c|c|c|}
\hline \multirow{2}{*}{ Item } & \multicolumn{2}{|c|}{ Male } & \multicolumn{2}{c|}{ Female } & \multirow{2}{*}{$\mathrm{t}$} & $\mathrm{p}$ \\
\cline { 2 - 5 } & $\mathrm{M}$ & $\mathrm{SD}$ & $\mathrm{M}$ & $\mathrm{SD}$ & & \\
\hline $\begin{array}{l}\text { Using mobile } \\
\text { learning, I } \\
\text { believe I can } \\
\text { maximize } \\
\text { learning effects } \\
\text { compared to } \\
\text { previous } \\
\text { learning method } \\
\text { (offline, cyber). }\end{array}$ & 3.34 & 0.916 & 3.22 & 0.852 & 2.57 & $0.010^{*}$ \\
\hline $\begin{array}{l}\text { I believe I can } \\
\text { easily learn the } \\
\text { functions of } \\
\text { mobile-learning } \\
\text { device. }\end{array}$ & 3.40 & 0.865 & 3.33 & 0.840 & 1.61 & 0.107 \\
\hline $\begin{array}{l}\text { I believe } \\
\text { application of } \\
\text { mobile learning } \\
\text { would be easy } \\
\text { because it is } \\
\text { similar to web- } \\
\text { based learning. }\end{array}$ & 3.35 & 0.869 & 3.28 & 0.838 & 1.63 & 0.104 \\
\hline $\begin{array}{l}\text { Within the } \\
\text { environment } \\
\text { with qualified } \\
\text { contents and } \\
\text { mobile-friendly } \\
\text { environment, I }\end{array}$ & 3.62 & 0.909 & 3.50 & 0.907 & 2.51 & $0.012^{*}$ \\
\hline
\end{tabular}




\begin{tabular}{|l|l|l|l|l|l|l|}
\hline $\begin{array}{l}\text { would actively } \\
\text { use it. }\end{array}$ & & & & & & \\
\hline $\begin{array}{l}\text { I have positive } \\
\text { attitudes toward } \\
\text { mobile learning. }\end{array}$ & 3.60 & 0.889 & 3.50 & 0.894 & 1.97 & 0.49 \\
\hline $\begin{array}{l}\text { I would like to } \\
\text { actively use } \\
\text { mobile learning } \\
\text { in the future. }\end{array}$ & 3.50 & 0.934 & 3.37 & 0.952 & 2.58 & 0.10 \\
\hline
\end{tabular}

The following is the analyzed result of attitudes toward mobile learning according to age. Except for the category of 'Using mobile learning, I believe I can maximize learning effects compared to previous learning method (offline, cyber)', all the categories showed significant differences. More specifically, the categories of 'I believe application of mobile learning would be easy because it is similar to web-based learning', 'I believe I can easily learn the functions of mobilelearning device', and 'Within the environment with qualified contents and mobile-friendly environment, I would actively use it', those in their 20s showed higher scores than those in their $50 \mathrm{~s}$, and those in their 40s showed higher scores than those in their 50s. In responding to the category of 'I have positive attitudes toward mobile learning', those in their 20s showed higher scores than those in their 50s. Furthermore, those in their 20s showed higher scores than those in their 50s and those in their 30s showed higher scores than those in their 50s in responding to the category of 'I would like to actively use mobile learning in the future'.

Table 13. Attitudes toward mobile learning according to age

\begin{tabular}{|c|c|c|c|c|c|}
\hline $\begin{array}{l}\text { Dependent } \\
\text { variable }\end{array}$ & Age & M & SD & $\begin{array}{l}\mathrm{F} / \mathrm{p}- \\
\text { value }\end{array}$ & Scheffe \\
\hline \multirow{4}{*}{$\begin{array}{l}\text { Using mobile } \\
\text { learning, I } \\
\text { believe I can } \\
\text { maximize } \\
\text { learning effects } \\
\text { compared to } \\
\text { previous } \\
\text { learning } \\
\text { method } \\
\text { (offline, cyber) }\end{array}$} & $20 \mathrm{~s}$ & 3.47 & 0.741 & \multirow{4}{*}{$\begin{array}{l}1.751 \\
/ 0.155\end{array}$} & \\
\hline & $30 \mathrm{~s}$ & 3.28 & 0.893 & & \\
\hline & $40 \mathrm{~s}$ & 3.27 & 0.860 & & \\
\hline & $\begin{array}{l}\text { over } \\
50 \mathrm{~s}\end{array}$ & 3.22 & 0.909 & & \\
\hline \multirow{4}{*}{$\begin{array}{l}\text { I believe I can } \\
\text { easily learn the } \\
\text { functions of } \\
\text { mobile-learning } \\
\text { device }\end{array}$} & $20 \mathrm{~s}$ & 3.59 & 0.737 & \multirow{4}{*}{$\begin{array}{l}10.203 \\
/ 0.000\end{array}$} & \multirow{4}{*}{$\begin{array}{l}\mathrm{d}<\mathrm{a} \\
\mathrm{d}<\mathrm{b} \\
\mathrm{d}<\mathrm{c}\end{array}$} \\
\hline & $30 \mathrm{~s}$ & 3.46 & 0.800 & & \\
\hline & $40 \mathrm{~s}$ & 3.39 & 0.845 & & \\
\hline & $\begin{array}{l}\text { over } \\
50 \mathrm{~s}\end{array}$ & 3.18 & 0.884 & & \\
\hline \multirow{4}{*}{$\begin{array}{l}\text { I believe } \\
\text { application of } \\
\text { mobile learning } \\
\text { would be easy } \\
\text { because it is } \\
\text { similar to web- } \\
\text { based learning }\end{array}$} & $20 \mathrm{~s}$ & 3.61 & 0.804 & \multirow{4}{*}{$\begin{array}{l}13.676 \\
/ 0.000\end{array}$} & \multirow{4}{*}{$\begin{array}{l}\mathrm{d}<\mathrm{a} \\
\mathrm{d}<\mathrm{b} \\
\mathrm{d}<\mathrm{c}\end{array}$} \\
\hline & $30 \mathrm{~s}$ & 3.43 & 0.790 & & \\
\hline & $40 \mathrm{~s}$ & 3.33 & 0.843 & & \\
\hline & $\begin{array}{l}\text { over } \\
50 \mathrm{~s}\end{array}$ & 3.12 & 0.873 & & \\
\hline Within the & $20 \mathrm{~s}$ & 3.81 & 0.849 & 9.655 & $\mathrm{~d}<\mathrm{a}$ \\
\hline
\end{tabular}

\begin{tabular}{|c|c|c|c|c|c|}
\hline \multirow{3}{*}{$\begin{array}{l}\text { environment } \\
\text { with qualified } \\
\text { contents and } \\
\text { mobile-friendly } \\
\text { environment, I } \\
\text { would actively } \\
\text { use it }\end{array}$} & $30 \mathrm{~s}$ & 3.68 & 0.889 & \multirow[t]{3}{*}{$/ 0.000$} & \multirow{3}{*}{$\begin{array}{l}\mathrm{d}<\mathrm{b} \\
\mathrm{d}<\mathrm{c}\end{array}$} \\
\hline & $40 \mathrm{~s}$ & 3.56 & 0.889 & & \\
\hline & $\begin{array}{l}\text { over } \\
50 \mathrm{~s}\end{array}$ & 3.38 & 0.937 & & \\
\hline \multirow{4}{*}{$\begin{array}{l}\text { I have positive } \\
\text { attitudes } \\
\text { toward mobile } \\
\text { learning }\end{array}$} & $20 \mathrm{~s}$ & 3.79 & 0.759 & \multirow{4}{*}{$\begin{array}{l}4.360 \\
/ 0.005\end{array}$} & \multirow{4}{*}{$\mathrm{d}<\mathrm{a}$} \\
\hline & $30 \mathrm{~s}$ & 3.61 & 0.925 & & \\
\hline & $40 \mathrm{~s}$ & 3.54 & 0.879 & & \\
\hline & $\begin{array}{l}\text { over } \\
50 \mathrm{~s}\end{array}$ & 3.44 & 0.901 & & \\
\hline \multirow{4}{*}{$\begin{array}{l}\text { I would like to } \\
\text { actively use } \\
\text { mobile learning } \\
\text { in the future }\end{array}$} & $20 \mathrm{~s}$ & 3.64 & 0.782 & \multirow{4}{*}{$\begin{array}{l}5.922 \\
/ 0.001\end{array}$} & \multirow{4}{*}{$\begin{array}{l}\mathrm{d}<\mathrm{a} \\
\mathrm{d}<\mathrm{b}\end{array}$} \\
\hline & $30 \mathrm{~s}$ & 3.52 & 0.930 & & \\
\hline & $40 \mathrm{~s}$ & 3.43 & 0.941 & & \\
\hline & $\begin{array}{l}\text { over } \\
50 \mathrm{~s}\end{array}$ & 3.28 & 0.978 & & \\
\hline
\end{tabular}

The following is the analyzed result of attitudes toward mobile learning according to position. The categories of 'I believe application of mobile learning would be easy because it is similar to web-based learning' and 'Within the environment of qualified contents and mobile-friendly environment, I would actively use it', the significant difference is shown. More specifically, in responding to the category of 'I believe application of mobile learning would be easy because it is similar to web-based learning', subordinate workers showed higher scores than managers. Moreover, in responding to the category of 'Within the environment of qualified contents and mobile-friendly environment, I would actively use it', others showed higher scores than middle-position managers.

Table 14. Attitudes toward mobile learning according to position

\begin{tabular}{|c|c|c|c|c|c|}
\hline $\begin{array}{c}\text { Dependent } \\
\text { variable }\end{array}$ & Position & M & SD & $\begin{array}{l}\mathrm{F} / \mathrm{p}- \\
\text { value }\end{array}$ & Scheffe \\
\hline \multirow{4}{*}{$\begin{array}{l}\text { Using mobile } \\
\text { learning, I } \\
\text { believe I can } \\
\text { maximize } \\
\text { learning effects } \\
\text { compared to } \\
\text { previous } \\
\text { learning method } \\
\text { (offline, cyber) }\end{array}$} & managers & 3.13 & 0.985 & \multirow{4}{*}{$\begin{array}{l}1.445 \\
/ 0.228\end{array}$} & \\
\hline & $\begin{array}{l}\text { middle- } \\
\text { position } \\
\text { managers }\end{array}$ & 3.28 & 0.871 & & \\
\hline & $\begin{array}{l}\text { subordinate } \\
\text { workers }\end{array}$ & 3.32 & 0.867 & & \\
\hline & others & 3.20 & 0.877 & & \\
\hline \multirow{4}{*}{$\begin{array}{l}\text { I believe I can } \\
\text { easily learn the } \\
\text { functions of } \\
\text { mobile-learning } \\
\text { device }\end{array}$} & managers & 3.21 & 0.925 & \multirow{4}{*}{$\begin{array}{l}2.828 \\
/ 0.037\end{array}$} & \\
\hline & $\begin{array}{l}\text { middle- } \\
\text { position } \\
\text { managers }\end{array}$ & 3.32 & 0.852 & & \\
\hline & $\begin{array}{l}\text { subordinate } \\
\text { workers }\end{array}$ & 3.47 & 0.793 & & \\
\hline & others & 3.38 & 0.865 & & \\
\hline \multirow{2}{*}{$\begin{array}{l}\text { I believe } \\
\text { application of } \\
\text { mobile learning }\end{array}$} & managers & 3.21 & 0.860 & \multirow{2}{*}{$\begin{array}{l}4.153 \\
/ 0.006\end{array}$} & \multirow[b]{2}{*}{$\mathrm{b}<\mathrm{c}$} \\
\hline & $\begin{array}{l}\text { middle- } \\
\text { position }\end{array}$ & 3.27 & 0.841 & & \\
\hline
\end{tabular}




\begin{tabular}{|c|c|c|c|c|c|}
\hline \multirow{3}{*}{$\begin{array}{l}\text { would be easy } \\
\text { because it is } \\
\text { similar to web- } \\
\text { based learning }\end{array}$} & managers & & & & \\
\hline & $\begin{array}{l}\text { subordinate } \\
\text { workers }\end{array}$ & 3.47 & 0.828 & & \\
\hline & others & 3.30 & 0.882 & & \\
\hline \multirow{4}{*}{$\begin{array}{l}\text { Within the } \\
\text { environment } \\
\text { with qualified } \\
\text { contents and } \\
\text { mobile-friendly } \\
\text { environment, I } \\
\text { would actively } \\
\text { use it }\end{array}$} & managers & 3.41 & 0.979 & \multirow{4}{*}{$\begin{array}{l}4.717 \\
/ 0.003\end{array}$} & \multirow{4}{*}{$\mathrm{b}<\mathrm{d}$} \\
\hline & $\begin{array}{l}\text { middle- } \\
\text { position } \\
\text { managers }\end{array}$ & 3.49 & 0.892 & & \\
\hline & $\begin{array}{l}\text { subordinate } \\
\text { workers }\end{array}$ & 3.66 & 0.871 & & \\
\hline & others & 3.68 & 0.967 & & \\
\hline \multirow[b]{2}{*}{$\begin{array}{l}\text { I have positive } \\
\text { attitudes toward } \\
\text { mobile learning }\end{array}$} & managers & 3.45 & 0.953 & \multirow[b]{2}{*}{$\begin{array}{l}1.134 \\
/ 0.334\end{array}$} & \\
\hline & $\begin{array}{l}\text { middle- } \\
\text { position } \\
\text { managers } \\
\text { subordinate } \\
\text { workers } \\
\text { others }\end{array}$ & $\begin{array}{l}3.59 \\
3.60\end{array}$ & $\begin{array}{l}0.899 \\
0.929\end{array}$ & & \\
\hline \multirow{3}{*}{$\begin{array}{l}\text { I would like to } \\
\text { actively use } \\
\text { mobile } \\
\text { learning in the } \\
\text { future }\end{array}$} & $\begin{array}{l}\text { managers } \\
\text { middle- } \\
\text { position } \\
\text { managers }\end{array}$ & 3.37 & 0.970 & \multirow{3}{*}{$\begin{array}{l}2.346 \\
/ 0.071\end{array}$} & \\
\hline & $\begin{array}{l}\text { subordinate } \\
\text { workers }\end{array}$ & 3.49 & 0.920 & & \\
\hline & others & 3.52 & 0.967 & & \\
\hline
\end{tabular}

\section{CONCLUSIONS AND IMPLICATIONS}

This study aimed to explore the learner recognition, experiences, and needs regarding mobile learning. The data was collected from the surveys of participants at MHWA. The following is the summary of this study.

First, participants responded that they have knowledge of mobile learning and they commonly used their cell phones as well as smart phones as learning devices. Second, the participants responded that they wanted contents of mobile learning which is related to their tasks at work. They replied that they also used mobile devices when they move from places to places. The main reason for using mobile learning is due to its mobility. Also, they used mobile devices because they can enjoy their leisure time. Third, the participants responded that they believe that mobile learning would be effective compared to e-learning. They would like to actively use mobile learning if the mobile environment is further developed. Based on the results of this study, the following implications can be drawn. First, some participants responded that they had already heard and knew about mobile learning. However, some of them did not see the necessity of mobile learning. Especially, aged people do not like high technology devices because they think that high technology is too complicated to use. This can be a cause of 'Digital Divide' which refers to inequalities between individuals, socioeconomic levels, other demographic categories or geographic areas [23]. Therefore, strategies of diffusing mobile learning would be needed in order to reduce the gap between individuals, generations and so on. This implies that a broad and intensive introduction of mobile learning is needed. Since a majority of the participants use smart phones as well as mobile devices, a gradual introduction of mobile learning taking into consideration type of device and fees is needed.

Second, many participants used mobile learning when they have spare time. Consideration of learning time and the form of contents should be viewed in advance. In the research, short-form mobile learning is a good idea to reduce cognitive load and to increase learners retention [24]. Most busy people want to invest in a training process very quickly. Therefore, the short form of mobile learning needs to be studied for busy people. Especially, in order to maximize work-related capability, a systematic strategy elicited from officers' work is needed. Moreover, the majority of the officers at the MHWA work in the field rather than in offices, thus, work-related manuals and problem-solving forms in the field should be considered.

Third, with an environment of mobile learning, several participants responded that they would become actively involved in mobile learning. This result leads to an implication on how to create a mobile learning environment. Putting it differently, a user-centered mobile interface environment should be established. Since participants are likely to use mobile learning in their leisure time, transformation into previous learned contents is required.

Fourth, learners' attitudes toward mobile learning are different according to gender, age, and position. According to the analyzed contents of learners' attitudes based on position and age, subordinate workers are likely to place more value on mobile learning compared to managers. This is because subordinate workers are more likely to spend time in the field compared to managers, thus, subordinate workers showed their willingness to actively use mobile learning. Therefore, in introducing mobile learning, a gradual and intensive introduction is needed considering these learner groups.

In conclusion, mobile learning could give people new learning opportunities and emphasize on social interactions [25]. Therefore, in order to introduce mobile learning, the analysis of learner characteristics and learner needs toward mobile learning are required because tasks and educational needs of learners vary. In this study, those in their 20 s and 30 s who have sufficient knowledge of information communication, showed strong willingness to participate in mobile learning compared to their counterparts. However, this study collected only quantitative data regarding learners' mobility and education in introducing mobile learning. Therefore, a further study involving qualitative research, such as in-depth interviews and observations, relating to learners' educational needs and mobile learning is called for. 


\section{REFERENCES}

[1] J. S. Han, "The strategy and the future of the mobile contents," Korea Contents Association Review, vol. 10, no. 1, Mar. 2012, pp. 12-15.

[2] S. B. Ha and S. M. Kang, "Inquiry on the Socio-cultural Meaning of the Using Form and Environment of Smart phone: Focused on the Viewpoint of Media-ecology Studies," Journal of the Korea Contents Association, vol. 11, no. 7, 2011, pp. 89-99.

[3] A. Kukulska-Hulme and J. Traxler Mobile learning: a handbook for educators and trainer, Routledge, 2005.

[4] L. S. Lee, K. S. Song, and Y. M. Lee, Ubiquitous Society and Mobile Learning, Seoul: Munym Ltd, 2006.

[5] J. H. Lim, "A Study on the Design Strategies of Teaching and Learning Model for Mobile Learning," The Journal of Korean Educational Forum, vol. 8, no. 1, 2008, pp. 1-20.

[6] J. M. Lee, "Overview of mobile learning service in Korea and abroad and implications toward cyber university which prepares a new era of mobile learning service," Cyber-society Culture, vol. 1, no. 1, 2011, pp. 91-119.

[7] Y. M. Lee and E. W. Chun, "The Analysis on Teaching and Learning Activities Using Mobile Devices in Higher Education," Journal of the Korea Contents Association, vol. 11, no. 2, 2011, pp. 477-486.

[8] S. M. Jin, Y. Kim, J. E. Lee, and Y. A. Oh, "Basic Research for Mobile Learning Introduction," Korea Human Resource Development Institute for Health \& Welfare, 2011, p. 26.

[9] C. O'Malley, G.Vavoula, J. Glew, J. Taylor, M. Sharples, and P. Lefrere, "Guidelines for learning, teaching, tutoring, in a mobile environment. Mobil learning project deliverable," http://www.mobilearn.org/download/results/ guidlines.pdf.

[10] L. Naismith, P. Londsdale, G. Vavoula, and M. Sharples, "2011 Literature Review in Mobile Technologies and Learning," Futurelab Series: Futurelab Retort 11, Bristol, UK. http://www.futurelab.org.uk/resources/publicationsreports-articles/literature-reviews/Literature-Review203/ (2011. 09.01)

[11] J. Attewell and C. Savill-Smith, Learning with mobile devices: research and development Learning and Skills Development Agency, London, UK, 2004.

[12] Goh and T. Kinshuk, "Getting ready for mobile learning: Adaptation perspective," Journal of Educational Multimedia and Hypermedia, vol. 15, no. 2, 2006, pp. 175-198.

[13] D. Keegan, "2011 The future learning: From e-learning to m-learning. Ziff Paper 119," Hagen: Fern University at. http://www.fernuni- hagen.de/ZIFF (2011. 09.01)

[14] A. Trifonova, Mobile learning: review of literature. Technical Report \# Dit-30-009, University of Toronto, 2002.

[15] C. Randell, S. Price, Y. Rogers, E. Harris, and G. Fitzpatrick, "The ambient horn: Designing a novel audiobased learning experience," Personal and Ubiquitous Computing, vol. 8, no. 3, 2004, pp. 144-161.

[16] M. Sharples and M. Milard, "I. Armadillo-Sánchez \& G. Vavoula, Mobile learning: Small devices, big issues," In N.
Balacheff, S. Ludvigsen, T. de Jong, A. Lazonder, S. Barnes, and L. Montandon (Eds.), Technology enhanced learning: Principles and products, Berlin: Springer, 2008, p. 80.

[17] M. Sharples, J. Taylor, and G. Vavoula, "A theory of learning for the mobile age," In R. Andrews and C. Haythronrhwaite (Eds.), The SAGE handbook of elearning research, London: Sage, 2007, p. 221-247.

[18] R. Guy, The evolution of mobile teaching and learning, Santa Rosa, California: Informing Science Press, 2009.

[19] M. Sharples, Big issues in mobile learning: Report of a workshop by the kaleidoscope network of excellence mobile learning initiative, London: Learning Science Research Institute, University of Nottingham, 2007.

[20] M. R. Kim, Spread of Web-based Education, Ra ilju(ed.), Seoul: Kyoyoobook Ltd, 1999.

[21] S. Whang, "Factors Affecting E-Learning Diffusion and Acceptance of Faculty in a Vocational Education and Training Institute," The Journal of Vocational Education Research, vol. 27, no. 3, 2008, pp. 25-41.

[22] Y. J. Yang, B. H. Park, and Y. S. Lim, "A Study on Factors Influencing the intention to use of m-Learning," The Journal of Educational Information and Media, vol. 11, no. 1, 2005, pp. 147-165.

[23] S. M. Jeong, et al. "Lifelong learning quality education eguide research lines developed," Korea Education \& Research Information Service Research Report CR 2008-3.

[24] M. Boyette, "Get Small: Reframe eLearning Design," Learning Solution Magazine. Access: http://www.learningsolutionsmag.com/articles/1404/getsmall-reframe-elearning-design.

[25] Y. E. Shin and D. Mills, "Setting the New Standard with Mobile Computing in Online Learning," International Review of Research in Open and Distance Learning, vol 8, no. 2. Jun. 2007.

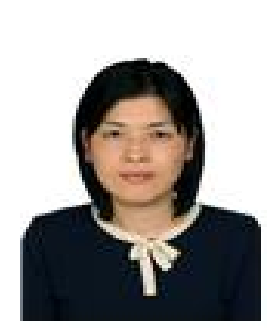

\section{Summi Jin}

She received the B.S. degree in mathematics from Cheon-ju University, Korea in 1995, respectively and also received M.S degree in education from Korean national university of education. Ph.D. course completion in Education Technology from Hanyang University, Korea in 1998 and 2007. Now she has been a professor at the Korea Human Resource Development Institute for Health \& Welfare. Her main research interests include education technology, media education. \& e-learning.

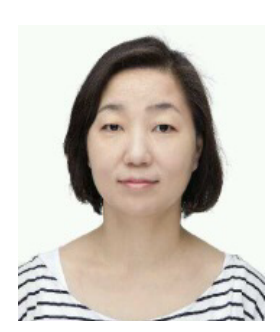

\section{Seunghye Hyun}

She received the B.S. degree in international business from Ohio State University, U.S.A., in 1999, respectively and also received M.S. degree and Ph.D. course completion in Education Technology from Hanyang University, Korea in 2007 and 2013. Her main research interests include education technology, media education. \& e-learning. 